\title{
Patterns of plant invasions at small spatial scale correspond with that at the whole country scale
}

\author{
Marcin K. Dyderski ${ }^{1,2}$ • Andrzej M. Jagodziński ${ }^{1,2}$
}

Published online: 13 January 2016

(C) The Author(s) 2016. This article is published with open access at Springerlink.com

\begin{abstract}
Invasions were studied at different spatial scales, however these scales were rarely compared. The aim of this study is to compare the rate of expansion of eight alien plant species within the borders of the city with expansion in the whole country and to analyse changes in distribution of these plant species in the last 30 years. We hypothesised that at the scale of the city, despite of stronger human impact, invasion processes will perform in a similar way as at the scale of whole country. Distribution changes of Bidens frondosa, Conyza canadensis, Echinocystis lobata, Helianthus tuberosus, Impatiens parviflora, Reynoutria japonica, Solidago canadensis and S. gigantea in $1 \mathrm{~km}$ squares grid was examined in the Warta River Valley in Poznan (W Poland) in 2013 and compared to data collected during 1980-1984. All species increased their distribution within the study area. E. lobata had the highest increment of occupied grid squares (from 0 in 1980's to 28 in 2013), and S. gigantea had the lowest (from 8 to 9). Echinocystis lobata reached the highest invasion success, which results from species traits (hydrochory) and large propagule pressure from garden plots. Between species with different ecological traits residence time has relatively little influence on invasion success, however in cases of species with similar traits ( $S$. canadensis and S. gigantea) residence time is a crucial factor determining invasion success. Although urban ecosystems are more vulnerable to biological invasions, this process occurs in a similar way as in the whole country. This similarity is connected with similar factors responsible for spread of invasive species: propagule pressure, time since introduction and spatial distributions of invasible habitats.
\end{abstract}

Keywords Invasive plant species $\cdot$ Riparian ecosystems $\cdot$ Urban ecology $\cdot$ Spread $\cdot$ Echinocystis lobata $\cdot$ Spatial pattern

Andrzej M. Jagodziński

amj@man.poznan.pl

1 Faculty of Forestry, Department of Forest Protection, Poznań University of Life Sciences, Wojska Polskiego 71c, 60-625 Poznań, Poland

2 Polish Academy of Sciences, Institute of Dendrology, Parkowa 5, 62-035 Kórnik, Poland 


\section{Introduction}

River valleys are habitats which are particularly vulnerable to biological invasions. Resource (water, light, nutrients) availability, as well as frequent disturbances caused by floods, facilitate encroachment of several plant species, including alien species (DeFerrari and Naiman 1994; Hood and Naiman 2000; Richardson et al. 2007; Dyderski et al. 2015). The river valleys in urban environments are especially endangered by invasive species, due to the important role of cities in biological invasions. This results from a high level of anthropogenic transformation of ecosystems (Pyšek and Prach 1993; Pyšek 1998; McKinney 2006; Knapp et al. 2010) and from high propagule pressure, as an effect of many ornamental alien species in cultivation in urban green areas (Pyšek 1998; McKinney 2006; Jarošík et al. 2011; Knapp et al. 2010; Kowarik et al. 2013; Dyderski et al. 2015).

River regulation and building embankments caused lack of episodic flows, which were responsible for shaping the successional gradient. This gradient represents the range of successional stages from the most pioneer conditions near the river bank, where only some shrubs may exist, to river valley slopes, where persistence of the forest community has not been interrupted by floods and late-successional plant communities may occur (DeFerrari and Naiman 1994; Hood and Naiman 2000; Richardson et al. 2007). River regulation increases the opportunities of invasion for many alien species of plants, especially those which benefit from ecosystem alteration (Cooper et al. 2003; Jagodziński and Maciejewska-Rutkowska 2005a, 2005b, 2008; Catford et al. 2011; Dyderski and Jagodziński 2014; Dyderski and Wrońska-Pilarek 2015).

Spread of alien plant species has two phases: slow increase of new localities (lag phase) and after that - quick spread and increase of new localities (log phase) (Kowarik 1995a; Lonsdale 1999; Kowarik et al. 2013). Length of the lag phase, when invasion is hard to detect, depends on length of the life cycle of the organism - annual species spread faster than perennials, and particularly faster than woody species (Pyšek and Prach 1993; Kowarik 1995a; Groves 2006). Moreover, Pyšek and Prach (1993) proved that river valleys may have different levels of importance among species during both invasive phases (lag and log). For example, for Heracleum mantegazzianum riparian habitats comprise $50 \%$ of occupied habitats in the lag phase, but only $10 \%$ during the log phase, while in the case of Impatiens glandulifera river valleys comprise $50 \%$ of its habitats in both invasion phases.

Spread of invasive species has been studied at different spatial scales since the beginning of invasion ecology, when Elton (1958) showed examples of studies on spread of alien species of animals and plants in the USA and Europe. For example, Tokarska-Guzik (2005) described the spread of chosen neophytes in Poland (country scale), and prepared maps showing the main directions of migration. Tabacchi and Planty-Tabacchi (2003) studied the spread of alien tree and shrub species along the Adour River Valley in France. Dyderski et al. (2015) analysed the changes in frequencies of alien trees and shrubs in the Warta River Valley in Poznań. These papers emphasised the increasing numbers of alien species located in river valleys. Also, in the above mentioned cases, rivers were important and effective pathways for alien species which use them to spread into other sites (Pyšek and Prach 1993).

Spatial scale of ecological process influences the number of potential predictors, rate, variety, possibility of increasing the number of replications and analytical approach. Processes studied at smaller spatial scales most frequently are explained by local factors, e.g. resource availability or physiological tolerance. In cases of bigger spatial scales, 
biogeographical factors, such as barriers, provide better explanations (Wiens 1989). Thus, there is a need for research regarding processes at different spatial scales. For example, Heller et al. (2006) studied the Argentine ant (Linepithema humile) invasion in North Carolina (USA), proving that seasonal behaviour changes, connected with colony establishment, influenced the dynamics of this species at the landscape scale. Pauchard and Shea (2006) pointed out differences in dispersal mechanisms and influence of invasive species at different spatial scales. They also claimed that there is a need to study biological invasions at different spatial scales to better understand the interactions between processes at these scales.

The aim of this study is to analyse changes in distribution of the most frequent neophytes in the Warta River Valley in Poznań (Poland) between the years 1980-84 (Jackowiak 1993) and 2013. An additional aim is to compare the rate of expansion of the species studied within borders of the city with data from expansion for Poland as a whole (Tokarska-Guzik 2005), to better recognize their spread mechanisms under strong human impact. We hypothesised that at the scale of the city, despite stronger human impact, biogeographic processes (i.e. expansion of alien species) will perform in a similar way as at the scale of the whole country.

\section{Methods}

The study covered the Warta River Valley in the administrative borders of Poznan City (Fig. 1). Poznań is a city located in Western Poland $\left(52^{\circ} 24^{\prime} \mathrm{N}, 16^{\circ} 57^{\prime} \mathrm{E}\right)$, with an area of $262 \mathrm{~km}^{2}$, and population of 550,700 (Statistical... 2013). The city is located in the temperate climate and long-term meteorological observations (1951-2010) showed that mean annual precipitation is $521 \mathrm{~mm}$ and mean annual temperature is $8.4^{\circ} \mathrm{C}$ (Statistical... 2013). The study area has been under strong human impact since the 10th century, when first settlement was established on the island in the Warta River. This settlement transformed into a city in 1253 and strongly increased its development starting in the late 19th century (Jackowiak 2011). The Warta River Valley runs a length of $23.3 \mathrm{~km}$ in Poznań and due to its ravine character is relatively narrow - widths vary from 200 to $1000 \mathrm{~m}$ (Dyderski et al. 2015). We assumed that the end of riparian terrace or artificial embankment was the edge of the river valley (Ratyńska 2001).

We divided the studied area into $1 \mathrm{~km}$ grid squares. This grid was based on the ATPOL grid (Zając and Zając 2001) (Fig. 1). The same grid was used by Jackowiak (1993), who examined flora of the whole city in 1980-1984. The study was conducted within 34 grid squares. Although some of grid squares are on the city boundaries, one may be afraid that it may compromise results, however our previous experiences in this area (Dyderski and Jagodziński 2014; Dyderski et al. 2015) shows that vegetation and types of land cover in the northern part of the city (Fig. 1) are similar to those in southern part, i.e. depend on the same factors and are both shaped mainly by land-use changes, e.g. deforestation or settlement. Moreover, Kowarik (1995b) claims that although the city political border is not an ecological border, in studies on urban plant cover it is an advantage, which allows comparison of zones with different human impact. According to the Corine Land Cover Urban Atlas of Poznań (European Environment Agency 2009), five of 17 classes had the highest cover among studied squares: 'Agricultural + Semi-natural areas + Wetlands', 'Forests', 'Green urban areas' (for these latter two classes misinterpretations of some areas were corrected), 'Industrial, commercial, public, military and private units', and 'Urban $>50 \%$ ' (two classes of urban cover combined: 'Continuous Urban Fabric, S.L. $>80$ \%' and 'Discontinuous Dense Urban Fabric, S.L.: 50 \% - 80 \%)' (Fig. 2). 


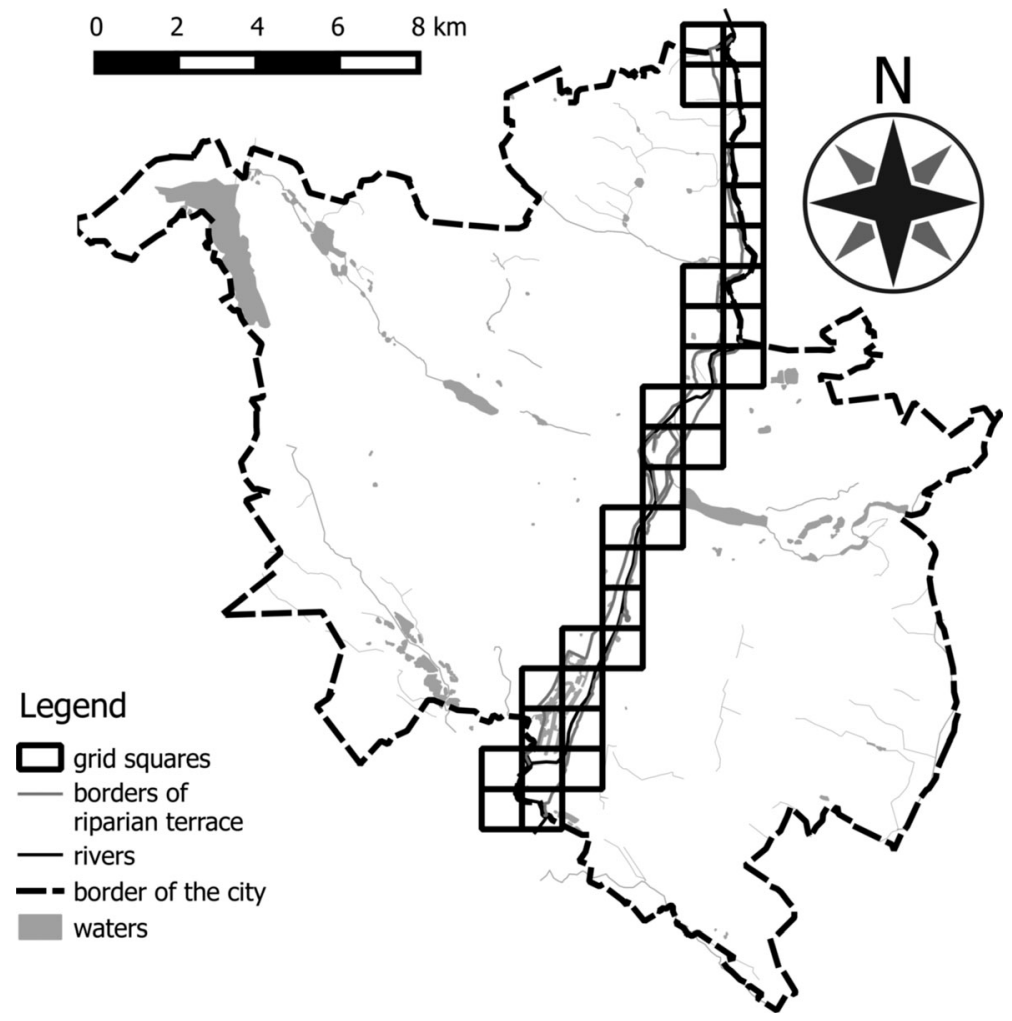

Fig. 1 Area of the study with grid of squares

Potential natural vegetation of the study area is composed of riparian forests with Salix spp., Populus spp. and Ulmus spp. and Quercus robur (Wojterski et al. 1982). Actual vegetation is a complex of riparian forests, deciduous forest with $Q$. robur, Tilia cordata and Carpinus betulus, artificial tree stands of Pinus sylvestris and Robinia pseudoaccacia, spontaneous tree stands of Acer negundo, as well as reeds, meadows, grasslands and ruderal vegetation.

In September 2013 we collected data on distribution of the most frequent alien herbaceous plant species. Based on field exploration in previous years and previous literature records, we chose eight species which occurred most frequently: Bidens frondosa, Conyza canadensis, Echinocystis lobata, Helianthus tuberosus, Impatiens parviflora, Reynoutria japonica, Solidago canadensis and S. gigantea. All these species are considered invasive in the whole of Poland (Tokarska-Guzik et al. 2012), as well as in the whole of Europe (Lambdon et al. 2008). Plant nomenclature follows Flora Europaea (Tutin et al. 1964-1993). Maps of the species distributions were prepared using R software (R Core Team 2015).

\section{Results}

All species studied increased their range in the study area since the 1980s. The highest increment of occupied grid squares occurred for Echinocystis lobata, which was not recorded 


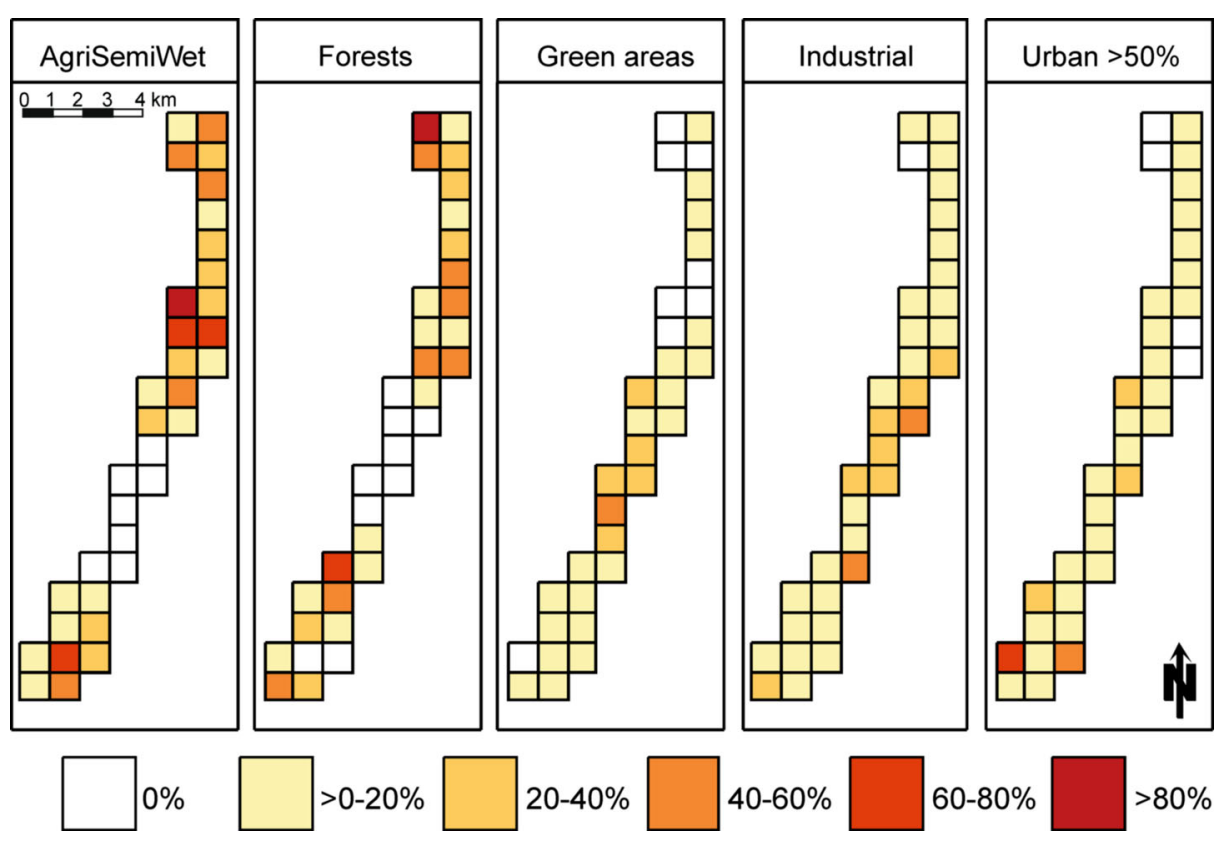

Fig. 2 Percent cover of the five most abundant types of land cover form in grid squares of the study area, according to Urban Atlas (European Environment Agency 2009). Types of land come from Corine Land Cover classification: AgriSemiWet - 'Agricultural + Semi-natural areas + Wetlands' class, Forests - 'Forests', Green areas - 'Green urban areas' (in case of these two classes misinterpretations of some area were corrected), Insustrial - 'Industrial, commercial, public, military and private units', Urban $>50 \%$ - combination of two classes: 'Continuous Urban Fabric (S.L. > 80 \%)' and 'Discontinuous Dense Urban Fabric (S.L.: 50 \% - 80 \%)'

in the Warta River Valley in Poznań in the 1980s, but was found in 28 squares in 2013. The lowest invasion dynamic was for Solidago gigantea - it increased from 8 to 9 grid squares (Fig. 3). In general, all species expanded their range among the grid squares and expanded into northern and southern, more forested areas, which were not invaded by them in the 1980s.

Bidens frondosa was recorded in 15 grid squares in the 1980s, mostly in the central part of the city (Fig. 4). It was less frequent in the southern part of the city. In 2013 B. frondosa occupied the whole southern part of the city and appeared in the northern part of the Warta River Valley. The most frequently occupied habitat for this species was the bank zone, on the mud with plant communities of inundation-zone terophytes (Bidens spp., Rumex spp. and Atriplex spp.). B. frondosa was also present in reeds of Phalaris arundinacea, shrubs of Salix spp., as well as in riparian forests with Salix alba and S. fragilis and in anthropogenic sites between concrete slabs, used to regulate the river channel in the central part of the city.

Conyza canadensis occurred in 18 grid squares in the 1980s, mainly in the central part of the city (Fig. 4). The largest solid area of C. canadensis occurrence covers the part of the river regulated by concrete slabs. In 2013, this species occurred in 27 grid squares, increasing its range into northern and southern parts of the city. Most frequently $C$. canadensis occurred in ruderal vegetation, between concrete slabs and on the slopes of embankments, where it mainly co-occurred with Calamagrostis epigejos.

In the 1980s Echinocystis lobata was not recorded in along the river Poznań, and in the whole city was recorded in only two of 242 squares (Jackowiak 1993). In 2013, E. lobata was recorded in 28 squares - the whole length of the Warta River Valley in Poznań. Most 


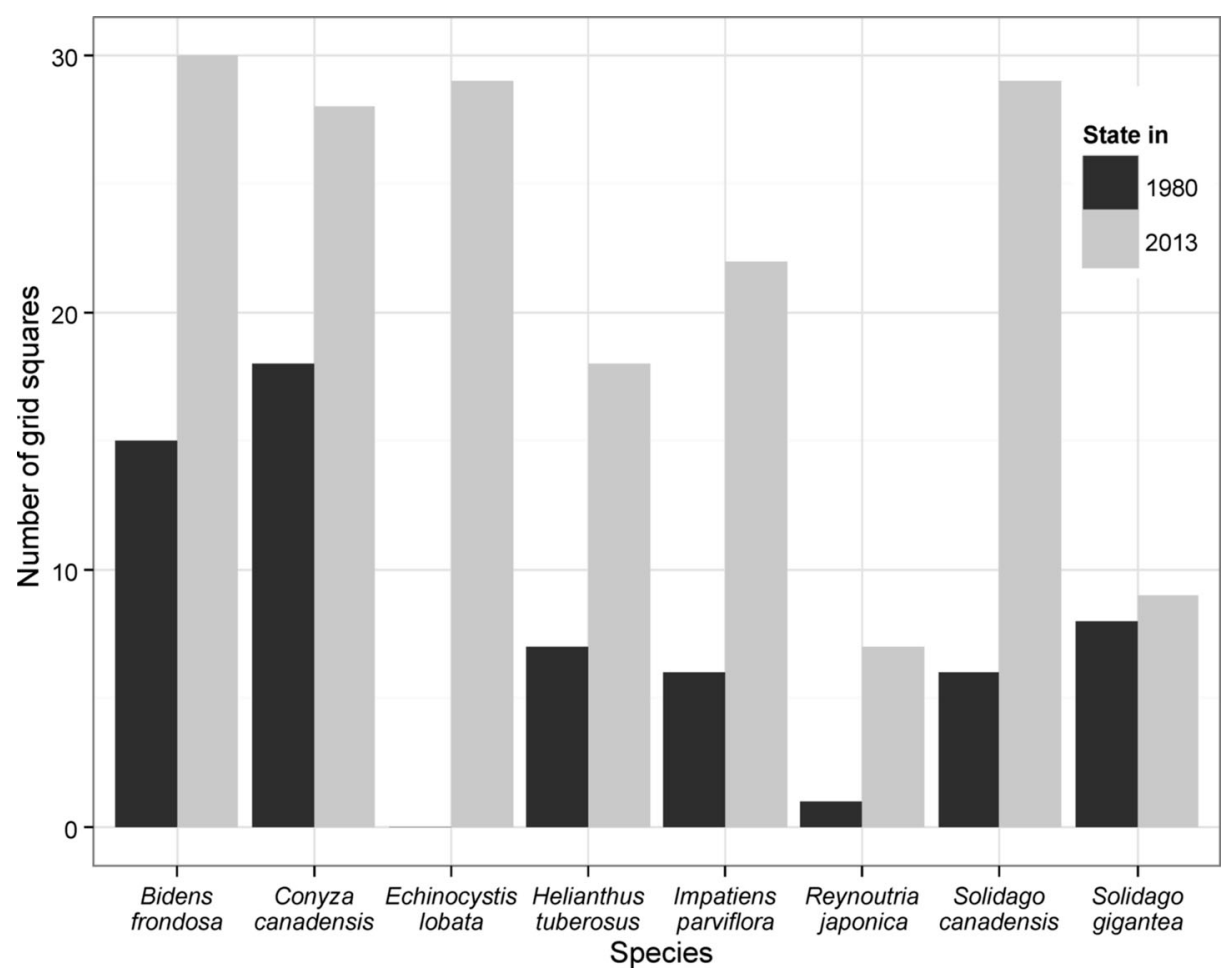

Fig. 3 Change in number of grid squares where each species studied was present between 1980 and 2013

frequently this species was recorded in shrub communities of Salix triandra, S. viminalis and S. purpurea, in riparian forests with Salix alba and S. fragilis, as well as in spontaneous, monoculture stands of invasive Acer negundo. E. lobata was also recorded in forest edges, reeds of Phalaris arundinacea and in shrub communities with Prunus spinosa, Cornus sanguinea, and Euonymus europaeus. Among all species studied, E. lobata was recorded in the highest number of grid squares.

Helianthus tuberosus occurred in seven grid squares in the 1980s, mainly in the central part of the city (Fig. 4). In 2013, this species was present in 18 grid squares, increasing its range into the southern part of the city. H. tuberosus was not recorded in the northern part of the city. Most frequently, this species occurred in small clumps with several specimens or in monoculture stands $20-50 \mathrm{~m}^{2}$ in size. The most numerous stands of $H$. tuberosus were recorded in grid squares with plot gardens.

In the 1980s Impatiens parviflora was recorded in six grid squares, localized in the central part of the city and in a forest complex in the southern part of the city (Fig. 4). In 2013, this species occurred in 22 grid squares, in both northern and southern parts of the city. In the central part of Poznań, its range was diffused. I. parviflora was the most numerous in grid squares with high fractions of forest area. This species was present in the understory of all types of forests in the study area.

Reynoutria japonica was recorded only in one grid square in the $1980 \mathrm{~s}$, in the southern part of the city (Fig. 5). In 2013 this species was recorded in seven grid squares: in the southern part of the city, around the locality recorded in the 1980s and in the central part of the city. In the each grid square, $R$. japonica occurred in a single stand. Each of these stands had an area of $3-$ 
Bidens frondosa

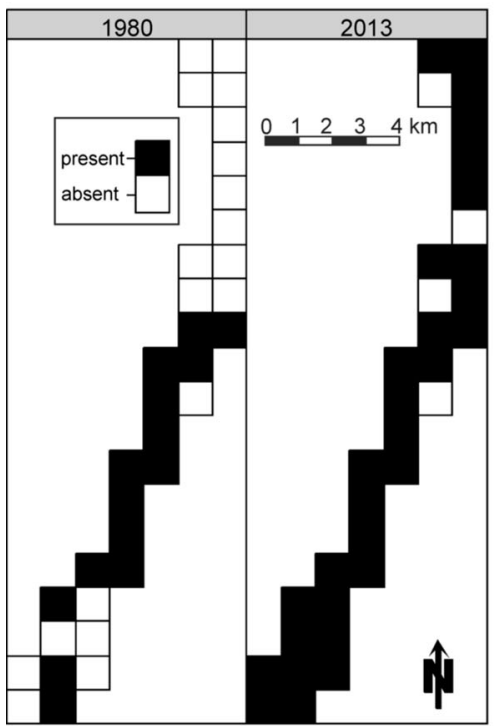

Echinocystis lobata

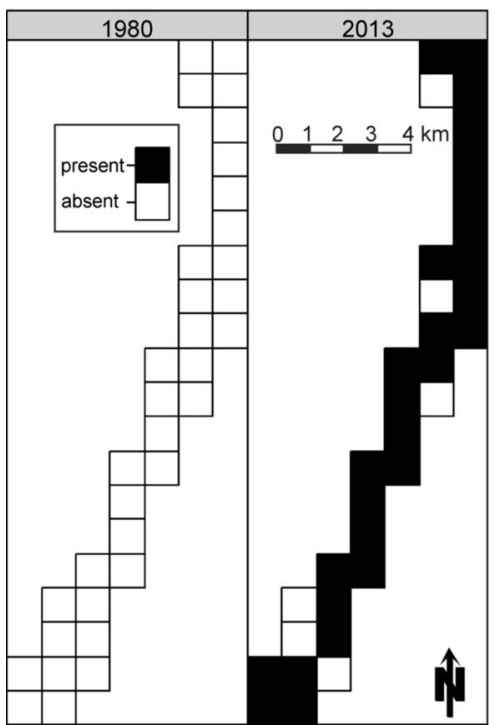

Conyza canadensis

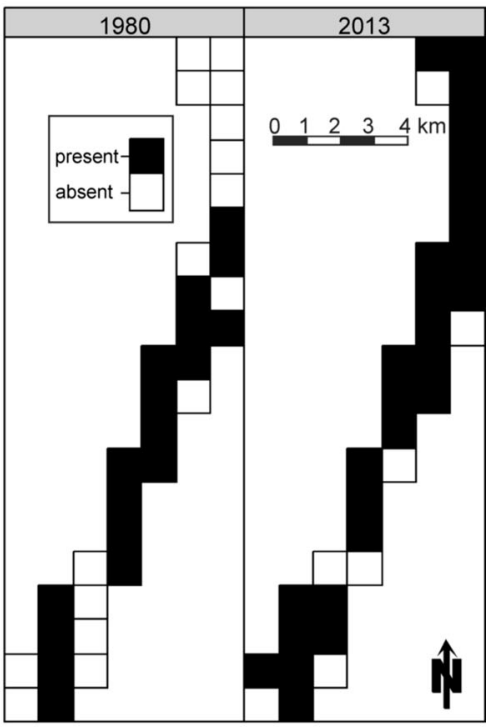

Helianthus tuberosus

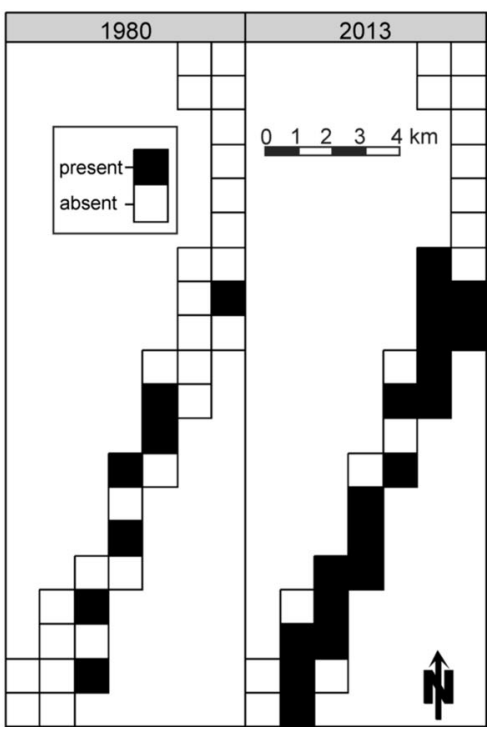

Fig. 4 Distribution of the species studied in 1980-1984 (Jackowiak 1993) and in 2013

$100 \mathrm{~m}^{2}$, and all of them occurred in ruderal habitats, mostly near bridges, paths and mounds of earth.

Solidago canadensis was recorded in six grid squares in the 1980s, in the southern and central part of the city (Fig. 5). In 2013, this species was present in 29 grid squares, nearly the whole length of the Warta River Valley. Most of its localities were found in ruderal plant communities, dominated by Calamagrostis epigejos, on the slopes of embankments and as monoculture stands. Rarely, S. canadensis was recorded at the forest edges. 
Impatiens parviflora

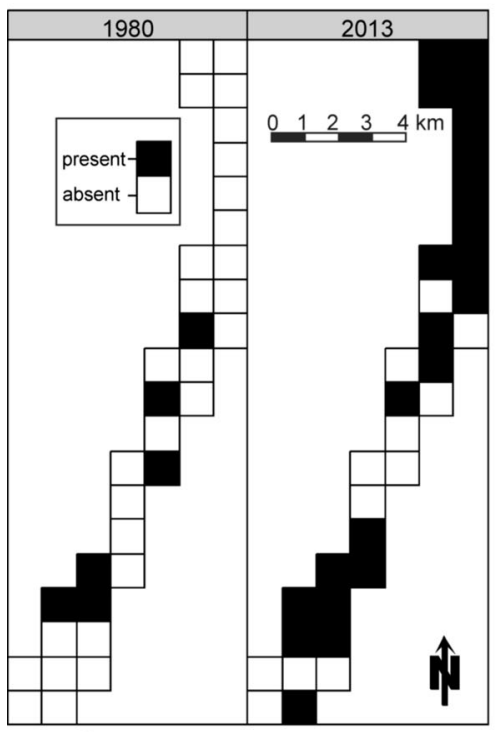

Solidago canadensis

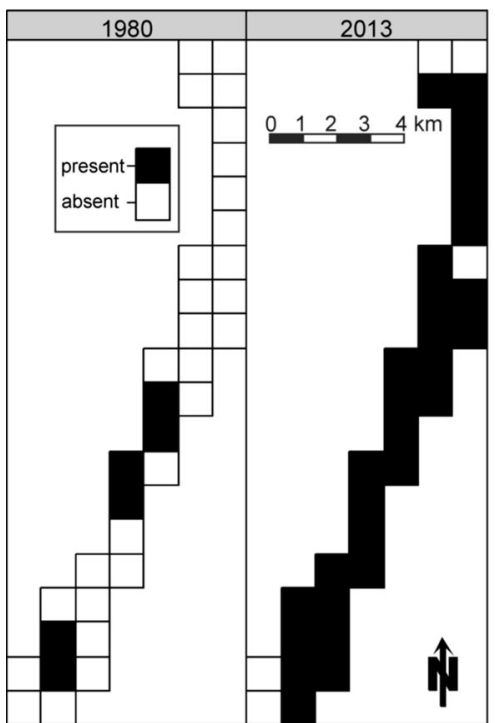

Reynoutria japonica

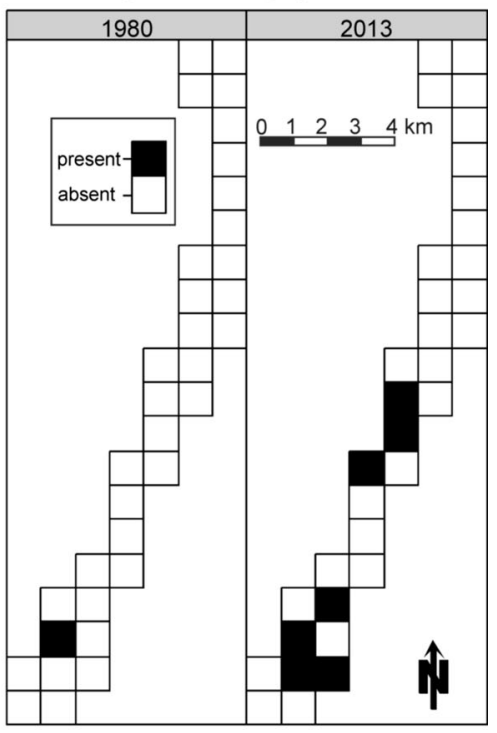

Solidago gigantea

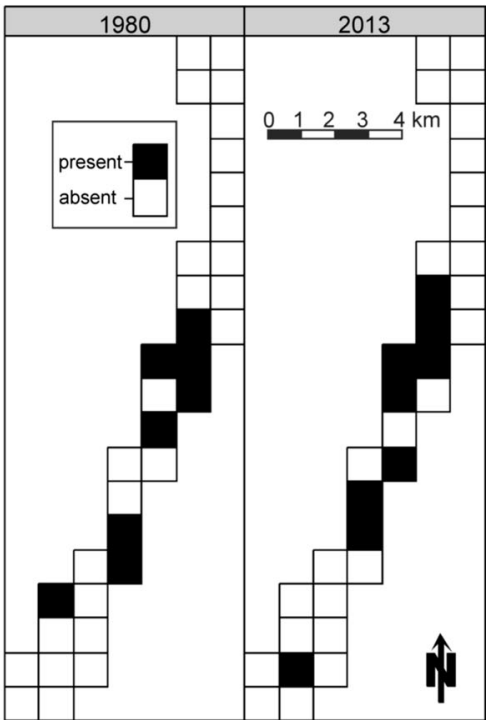

Fig. 5 Distribution of the species studied in 1980-1984 (Jackowiak 1993) and in 2013

Solidago gigantea was recorded in seven grid squares in central and southern part of the city in the 1980s (Fig. 5). In 2013 this species was present in eight grid squares, mainly in the central part of the city, and was absent from some grid squares where it had been present in the 1980s. Most S. gigantea localities were in ruderal habitats, mainly on the slopes of embankments and as monoculture stands or in complex with S. canadensis. 


\section{Discussion}

All of the species studied in the Warta River Valley in Poznan extended their range during the last 30 years. This observation confirms both high efficiency of riverine valleys as invasion pathways and high invasibility of river valleys. This invasibility results from availability of necessary resources (water, light and nutrients), as well as from frequent disturbances which create new, empty habitats, without the limiting influence of competitors (Pyšek and Prach 1993; Davis et al. 2000; Hood and Naiman 2000; Richardson et al. 2007). One may expect that if the main type of disturbance (i.e. episodic floods) were strongly limited by river regulation caused by the building of a reservoir dam in 1986 (Jeziorsko; $51^{\circ} 47^{\prime} 13^{\prime \prime} \mathrm{N}$ $18^{\circ} 39^{\prime} 30^{\prime \prime} \mathrm{E}$ ), then the riparian ecosystem will have a lower proportion of pioneer conditions and lower occurrence of invasive species that take advantage of these conditions. On the other hand, some authors claim that limitation of river flows is a factor that facilitates the invasion of alien plant species (Cooper et al. 2003; Tabacchi and Planty-Tabacchi 2003; Catford et al. 2011; Greet et al. 2015). This may be confirmed by studies conducted in the Warta River Valley on alien woody species - Dyderski et al. (2015) found that the most frequent woody alien species were species typical of mid-successional stages in their primary range - Acer negundo, Fraxinus pennsylvanica and Robinia pseudoacacia. Results of this study indicate that the range expansion of neophytes was observed not only in cases of species occurring mainly in frequently disturbed habitats (i.e. B. frondosa or C. canadensis), but also species connected with late-successional stages, such as I. parviflora. This suggests that limitation of river floods either facilitates the neophyte expansion or has no influence on it.

Until recently, Bidens frondosa was a not frequent element of the Warta River Valley flora. Its expansion theoretically would be limited by lower intensity of river floods, which shapes its optimal habitats - sandbanks and mud (Brzeg and Ratyńska 1983; Ratyńska 2001). However, as a therophyte producing high numbers of seeds, $B$. frondosa realised the ruderal life strategy, which allowed this species to colonize anthropogenic habitats and forest edges. The first locality of this species in Poznań was found in 1959 (Jackowiak 1993). Brzeg and Ratyńska (1983) found that in 1960 B. frondosa had only two localities in Poznań. This species was not recorded by Krawiecowa (1951), who found occurrence of B. connata, a related congeneric species, which also comes from North America. This species was expected to increase its invasion after 1945, however Jackowiak (1993) did not confirm the localities found by Krawiecowa (1951) and found this species only in one grid square, outside the Warta River Valley.

Bidens frondosa displaces the native congeneric species - B. tripartita (Urbisz et al. 2009; Dyderski and Jagodziński 2014). Jackowiak (1993) recorded B. tripartita in 15 grid squares in the Warta River Valley in 1980s, and 61 squares in the whole city, whereas $B$. frondosa in the whole city was recorded only in 29 grid squares. The large decrease of $B$. tripartita distribution (found only in two grid squares) may indicate competitive displacement of native species by the alien. $B$. tripartita reaches a lower height than B. frondosa (Rutkowski 2011), and requires insect pollination, whereas B. frondosa is most frequently self-pollinated (Klotz et al. 2002). Most probably these traits may be responsible for the invasion success of $B$. frondosa.

Conyza canadensis is a species connected with ruderal habitats and very common in Poznan city. In the 1980 s C. canadensis occurred in $70 \%$ of grid squares in the whole city, as a widely distributed kenophyte (Jackowiak 1993; Jackowiak 2011) as well as in the whole of Poland (80.3\% of ATPOL $10 \times 10 \mathrm{~km}$ grid squares) (Tokarska-Guzik 2005). In Poznań 
C. canadensis was recorded from the year 1850, mainly on ruderal sites (Krawiecowa 1951; Jackowiak 1993). In the study area this species occurred frequently, but its stands were not numerous. Most often its stands were found in ruderal sites, consistent with $C$. canadensis life strategy (Klotz et al. 2002). Probably the success of this species is largely determined by relatively long (according to the length of $C$. canadensis life cycle) time since introduction, similar to the case of woody invasive species studied by Pyšek et al. (2009).

Echinocystis lobata is one of the relatively new adventives species in Poland - with the first occurrence in 1937. However E. lobata has recently started to spread (Tokarska-Guzik 2005). In Poznań this species was not recorded before 1980 (Jackowiak 1993), and in 1980-84 it occurred in only two grid squares (with distances of 3 and $4 \mathrm{~km}$ from the Warta River Valley). The first locality of E. lobata in the study area was the central/northern part of the city (KluzaWieloch et al. 2005) and in 'Dębina' forest in the southern part of the city (2006 unpbl. obs.). Both places are located near garden plots, which are the main sources of this species' invasions in Europe (DAISIE 2007; Dajdok and Kącki 2009). Therefore, probably ornamental cultivation of this species causes high propagule pressure, which is one of the most important factors determining the strength of biological invasions (Lonsdale 1999; Lockwood et al. 2005; Křivánek et al. 2006; Pyšek et al. 2009; Zając et al. 2011). As a liana, E. lobata is able not only to occur in open plant communities (e.g. reeds and forest edges), but also liana communities (with Humulus lupulus, Calystegia sepium and Cuscuta spp.), shrub communities and riparian forests with Salix alba and S. fragilis (Dyderski and Jagodziński 2014). E. lobata shows similar invasion dynamics in the Polish Carpathians - with high growth in number of localities after 1990 (Zając et al. 2011), and is very invasive in other river valleys in Central Europe (Tokarska-Guzik 2005; DAISIE 2007; Dajdok and Kącki 2009).

Helianthus tuberosus is a species connected with open habitats, similar to C. canadensis. Krawiecowa (1951) mentioned that H. tuberosus occurred in Poznań since 1850, but it was frequently planted by German occupation authorities during World War II and around 1943 this species started expansion, mainly into anthropogenic sites. In the $1980 \mathrm{~s}$ this species occurred in scattered locations throughout the city, in 87 of 242 grid squares (Jackowiak 1993). A rapid rise in number of localities also occurred at the whole country scale in Poland during the second half of the 20th century (Tokarska-Guzik 2005). H. tuberosus is a species which reproduces both generatively and vegetatively, and with high regeneration abilities (Bzdega et al. 2009), which is a good adaptation to frequent disturbances in river valleys (Richardson et al. 2007). Lack of this species in the northern part of the city may be explained by the high fraction of forested areas there, whereas this species most frequently was recorded in open sites - in ruderal and forest edge vegetation, but not in riparian forests (Bzdęga et al. 2009; Żołnierz et al. 2011). Therefore, despite the high dispersal success and invasive potential of H. tuberosus, it will probably not invade riparian forests.

Impatiens parviflora is a widely-dispersed therophyte, which is able to invade most forest plant communities (Tokarska-Guzik 2005; Zerbe and Wirth 2006; Chmura 2014). In the study area, I. parviflora occurred in all types of forest plant communities (Ratyńska, 2001; Dyderski and Jagodziński 2014; Dyderski and Wrońska-Pilarek 2015), being a frequent and persistent understory element. Ability to tolerate forest understory conditions combined with effective dispersal, makes I. parviflora a highly successful invader. Moreover, grid squares with new I. parviflora localities, are mostly those 
with high fraction of forested area. I. parviflora was not recorded in riparian forests with Salix alba and S. fragilis in the Lower Oder River Valley (Borysiak 2004) and in the Warta River Valley (Borysiak 1994). In Poznań, this species was recorded for the first time in 1927, and in the 1950s it spread only to anthropogenic sites (Krawiecowa 1951). In the 1980s this species was present in parts of the forest plant communities in the Warta River Valley in Poznań (Ratyńska 2001). At the whole country scale, the exponential phase of Impatiens parviflora invasion also started after the 1970s (Tokarska-Guzik 2005; Chmura 2014).

Reynoutria japonica was first recorded in Poznań in 1949. In the 1980s, in the whole city this species was present in 12 of 242 grid squares (Jackowiak 1993). At the whole Poland scale, the highest increment in number of localities occurred after 1960 (Tokarska-Guzik 2005). $R$. japonica is considered one of the most potentially damaging invasive plant species (Bailey et al. 1996; Mandák et al. 2004; Tokarska-Guzik 2005; Sîrbu and Oprea 2008; Tokarska-Guzik et al. 2012). Therefore, a relatively small rate of invasion may be an effect of low spread efficiency, or $R$. japonica may not yet have reached the exponential increase phase for number of localities (i.e. still in invasion lag-phase). The latter may be confirmed by the highly dynamic spread of this species in other localities (Bailey et al. 1996; Mandák et al. 2004), especially in Carpathian river valleys (Zając et al. 2011).

Between the two species of Solidago studied ( $S$. canadensis and $S$. gigantea) there is a difference in dispersal success $-S$. canadensis occupied more grid squares. Both species were recorded for the first time in Poland in the second half of the 19th century. At the scale of the whole country, S. gigantea was found in $45.7 \%$ of ATPOL grid squares, and S. canadensis in $34.4 \%$. Both species increased their range after 1970 (Tokarska-Guzik 2005). Detailed study conducted by Szymura and Szymura (2013) in SW Poland, showed that S. gigantea was more numerous than other species of Solidago. S. canadensis and S. gigantea have very similar biologies, however they differ in urbanity indicator - Klotz et al. (2002) found that $S$. gigantea is a moderately urbanophobous species and that $S$. canadensis is urbanoneutral. However, distribution of both species in the whole city in 1980 did not indicate these differences $-S$. gigantea was more numerous (68 of 242 grid squares) than $S$. canadensis (64 grid squares) (Jackowiak 1993). The reason for higher success of $S$. canadensis in the study area may be longer residence time in Poznań. S. canadensis was first recorded in the city in 1928, whereas the first record of S. gigantea came in 1947 (Jackowiak 1993). Length of residence time is significant for spread of invasive species - the probability that the log phase of invasion will start increases with the length of residence time (Kowarik 1995a; Sukkop and Wurzel 2003; Lockwood et al. 2005; Groves 2006; Křivánek et al., 2006; Pyšek et al. 2009). Szymura and Szymura (2013) claimed that predominance of one Solidago species over another is an effect of earlier establishment in the site of interest, which may explain the success of $S$. canadensis.

High frequency of invasive plant species which are not related to riparian forests, probably result from strong deforestation of the Warta River Valley and the extent and distribution of ruderal vegetation. Moreover, species which invade forest plant communities ( $B$. frondosa, E. lobata, I. parviflora) occur also in ruderal and forest edge vegetation. This indicates a hierarchy of invasiveness - the above mentioned species seem to be more invasive than species which may have more extensive ranges and longer residence times (e.g. Conyza canadensis), but are not able to invade more natural ecosystems (e.g. riparian forests). This assumption may show that species traits which facilitate range expansion (e.g. hydrochory or 
anemochory) are more important variables responsible for invasion success than residence time. This differs from the results of Pyšek et al. (2009), who found that residence time is one of the most important predictors of invasion risk. Most probably this difference between studies may be attributed to shorter length of lag phase of herbaceous invasive plants studied here, compared to woody species in the other study (Pyšek and Prach 1993; Kowarik 1995a). On the other hand, differences in number of grid squares occupied by both Solidago species ( $S$. canadensis and $S$. gigantea) indicate that longer residence time may be important for invasion. Probably, in the case of these two congeneric species, with similar biology and functional traits, earlier emergence in the site under consideration may be crucial for invasion success.

Dynamics of the species invasions studied seem to depend on time since introduction and previously occupied area. As mentioned above, the species studied appeared in the Warta River Valley at different times. Those species which were first recorded in the first half of 19th century did not reach a relatively high increase of occupied grid squares number, which may be connected with the fact that they have established in most of the suitable areas; thus their range expansions may be not be in the first stage of invasion, but rather in late stages where there are few opportunities to colonize additional sites. In case of the recently found invasive species (i.e. Echinocystis lobata), its spread is in the log-phase of invasion (Kowarik 1995a), and probably will stop when they have occupied most of the suitable habitats.

At scales of both the whole country scale and of Poznan, ornamental use was a very important factor determining spread of the species studied (Pyšek et al. 2009; Kowarik et al. 2013). Grid squares where garden plots and parks were present, were often the places of first escape or release for invasion events. Although garden plots are usually smaller than parks, this type of urban greening is richer in alien species (Speak et al. 2015). Their locality in the river valley facilitates naturalization of alien plants. The same pattern was found in the Warta River Valley for the case of woody alien plants (Dyderski et al. 2015), where most of the alien species found were introduced for ornamental purposes.

The central part of the study area, which is also the city center, is the most invaded part of the city. This is connected with a stronger anthropogenic disturbance regime, which in turn facilitates the occurrence of alien plant species (Kowarik 1995b). Although the city center of Poznań is close to the river, it is not the part of the city most covered by buildings and pavement (Fig. 2). However, it is the part of the Warta River Valley most frequently visited by inhabitants and tourists, which confirms the positive relationship between number or proportion of alien species and human population size, expressed as number of inhabitants or number of visitors in national parks (Pyšek 1998; Lonsdale 1999). Moreover, the central part of the study area has a relatively high (20-40\%) cover of industrial land-use type (Fig. 2), which is considered a suitable habitat for alien plant species (Kowarik 1995b). Forests in the northern part of the city, which is less covered by urban fabric than the city center and southern part, were the least invaded by the species studied. This may also be an effect of later incorporation of the northern part into the city than the southern part. Thus, these results may lead to the assumption that quantifying the effect of urbanity is very difficult, because it results not only from distance to city center and cover of buildings, but also from time since urbanization and cover of other land-use forms.

In the study area, the phenomena described at a smaller spatial scale correspond to those at a larger spatial scale. Urban ecosystems are more vulnerable to biological invasions than other areas (Pyšek 1998; McKinney 2006; Knapp et al. 2010; Jarošík et al. 2011; Williams et al. 2015). Thus, one may expect that rate of invasive species spread would be higher and 
different mechanisms would drive this process. In the Warta River Valley, rates and patterns of the invasive species studied are similar to those described at the scale of the whole country (Tokarska-Guzik 2005). The similarities were found for both similar timing of quick increase in number of localities occupied and dynamics since introduction, as well as for similar factors responsible for their spread: occurrence of effective propagule sources (e.g. green areas, gardens) and spatial distributions of invasible habitats, which are crucial harbours for them, especially in early invasion stages.

\section{Conclusions}

In the last 30 years, all species studied extended their range into new localities, but their dispersal success was different - number of new grid squares among species ranged from $2.9 \%$ to $82.3 \%$ of all grid squares. Echinocystis lobata reached the highest invasion success, which resulted from species traits (hydrochory) and large propagule pressure in garden plots. In the case of goldenrods, the predominance of Solidago canadensis over S. gigantea most probably was an effect of longer residence time in the study area. Most of the species studied occurred mainly in open habitats in ruderal vegetation with Calamagrostis epigejos and slopes of embankments. However, some of them were able to invade the understory of riparian forests (Bidens frondosa, Echinocystis lobata and Impatiens parviflora), being a threat to the most precious ecosystems of the study area. Although urban ecosystems are more vulnerable to biological invasions, this process occurs in a similar way as in the whole country, which suggests that invasion of alien species of plants occurs in a similar way in both smaller (river valley in the city) and larger (whole country) spatial scales. This similarity is connected with similar factors responsible for spread of invasive species: propagule pressure, time since introduction and spatial distributions of invasible habitats.

Acknowledgments We would like to thank Dr. Lee E. Frelich (Department of Forest Resources, University of Minnesota, USA) for valuable suggestions and linguistic revision of the manuscript. We are also grateful to two anonymous Reviewers, which helped improving the earlier draft of the manuscript. We thank Mr. Jarosław Tyborski for technical assistance with Corine Land Cover Urban Atlas revision and corrections. The study was partially supported by the Institute of Dendrology, Polish Academy of Sciences, Kórnik, Poland.

Open Access This article is distributed under the terms of the Creative Commons Attribution 4.0 International License (http://creativecommons.org/licenses/by/4.0/), which permits unrestricted use, distribution, and reproduction in any medium, provided you give appropriate credit to the original author(s) and the source, provide a link to the Creative Commons license, and indicate if changes were made.

\section{References}

Bailey JP, Child LE, Conolly AP (1996) A survey of the distribution of Fallopia x bohemica (Chrtek \& Chrtkova) J Bailey (Polygonaceae) in the British Isles. Watsonia 21:187-198

Borysiak J (1994) Struktura aluwialnej roślinności lądowej środkowego i dolnego biegu Warty. Wydawnictwo Naukowe UAM, Poznań

Borysiak J (2004) Plant cover of the Lower Oder River Valley Landscape Park. Wydawnictwo Naukowe UAM, Poznań

Brzeg A, Ratyńska H (1983) Nadbrzeżne zbiorowiska roślinne nad Wartą w Poznaniu i ich cechy antropogeniczne. Bad Fizjogr Pol Zach B 45:7-40 
Bzdęga K, Nowak T, Tokarska-Guzik B (2009) Gatunki z rodzaju słonecznik Helianthus spp. In: Dajdok Z, Pawlaczyk P (eds) Inwazyjne gatunki roślin ekosystemów mokradłowych Polski. Wydawnictwo Klubu Przyrodników, Świebodzin, pp. 100-104

Catford JA, Downes BJ, Gippel CJ, Vesk PA (2011) Flow regulation reduces native plant cover and facilitates exotic invasion in riparian wetlands. J Appl Ecol 48:432-442. doi:10.1111/j.1365-2664.2010.01945.x

Chmura D (2014) Biology and ecology of an invasion of Impatiens parviflora DC in natural and semi-natural habitats. Wydawnictwo ATH, Bielsko-Biała

Cooper DJ, Andersen DC, Chimner RA (2003) Multiple pathways for woody plant establishment on floodplains at local to regional scales. J Ecol 91:182-196. doi:10.1046/j.1365-2745.2003.00766.x

Core Team R (2015) R: A language and environment for statistical computing. R Foundation for Statistical Computing, Vienna, Austria

DAISIE EIASG (2007) Echinocystis lobata. Available from: http://wwweurope-aliensorg/speciesFactsheetdo? speciesId=14766 Accessed 4 December 2015

Dajdok Z, Kącki Z (2009) Kolczurka klapowana Echinocystis lobata. In: Dajdok Z, Pawlaczyk P (eds) Inwazyjne gatunki roślin ekosystemów mokradłowych Polski. Wydawnictwo Klubu Przyrodników, Świebodzin, pp 52-53

Davis MA, Grime JP, Thompson K (2000) Fluctuating resources in plant communities: a general theory of invasibility. J Ecol 88:528-534. doi:10.1046/j.1365-2745.2000.00473.x

DeFerrari CM, Naiman RJ (1994) A multi-scale assessment of the occurrence of exotic plants on the Olympic Peninsula, Washington. J Veg Sci 5:247-258. doi:10.2307/3236157

Dyderski MK, Jagodziński AM (2014) Synantropizacja zbiorowisk łęgowych ze związku Salicion albae w południowej części Poznania. Acta Bot Sil 10:41-69

Dyderski MK, Wrońska-Pilarek D (2015) Szata roślinna nowo powstałych użytków ekologicznych „Dębina I” i „Dębina II” w Poznaniu. Nauka Przyr Tech, 9(4):\#46. doi:10.71306/J.NPT.2015.4.46

Dyderski MK, Gdula AK, Jagodziński AM (2015) “The rich get richer" concept in riparian woody species - A case study of the Warta River Valley (Poznań, Poland). Urban For Urban Green 14:107-114. doi:10.1016/j. ufug.2014.12.003

Elton CS (1958) The Ecology of Invasions by Animals and Plants. University of Chicago Press, Chicago

European Environment Agency (2009) Urban Atlas - Poznań. URL: http://wwweeaeuropaeu/data-and-maps/ data/urban-atlas Accessed: 4 December 2015

Greet J, Webb JA, Cousens RD (2015) Floods reduce the prevalence of exotic plant species within the riparian zone: evidence from natural floods. Appl Veg Sci 18:503-512. doi:10.1111/avsc.12156

Groves RH (2006) Are some weeds sleeping? Some concepts and reasons. Euphytica 148:111-120. doi:10.1007/ s10681-006-5945-5

Heller NE, Sanders NJ, Gordon DM (2006) Linking temporal and spatial scales in the study of an Argentine ant invasion. Biol Invasions 8:501-507. doi:10.1007/s10530-005-6411-3

Hood WG, Naiman RJ (2000) Vulnerability of riparian zones to invasion by exotic vascular plants. Plant Ecol 148:105-114. doi:10.1023/A:1009800327334

Jackowiak B (1993) Atlas rozmieszczenia roślin naczyniowych w Poznaniu. Bogucki Wydawnictwo Naukowe, Poznań

Jackowiak B (2011) Poznań. In: Müller N, Kelcey JG (eds) Plants and Habitats of European Cities. Springer, New York, pp. 363-405

Jagodziński AM, Maciejewska-Rutkowska I (2005a) Flora naczyniowa i roślinność rezerwatu "Ostrów Panieński” koło Chełmna. Parki Nar Rez Przyr 24:61-87

Jagodziński AM, Maciejewska-Rutkowska I (2005b) Warunki przyrodnicze rezerwatu “Ostrów Panieński” koło Chełmna w ujęciu historycznym. Parki Nar Rez Przyr 24:39-59

Jagodziński AM, Maciejewska-Rutkowska I (2008) Zmiany we florze rezerwatu przyrody "Ostrów Panieński” koło Chełmna w latach 1965-2001. Studia Naturae 54:121-131

Jarošík V, Pyšek P, Kadlec T (2011) Alien plants in urban nature reserves: from red-list species to future invaders? NeoBiota 10:27-46. doi:10.3897/neobiota.10.1262

Klotz S, Kühn I, Durka W (2002) BIOLFLOR - Eine Datenbank zu biologisch-ökologischen Merkmalen der Gefäßpflanzen in Deutschland. Schriftenreihe für Vegetationskunde. Bundesamt für Naturschutz, Bonn

Kluza-Wieloch M, Klimko M, Janyszek M, Janyszek S (2005) Flora of ecological areas "Różany Młyn" and "Wilczy Młyn" in Poznań. Roczniki Akademii Rolniczej w Poznaniu CCCLXXIII Botanika-Steciana 9: $149-170$

Knapp S, Kühn I, Stolle J, Klotz S (2010) Changes in the functional composition of a Central European urban flora over three centuries. Perspect Plant Ecol 12:235-244. doi:10.1016/j.ppees.2009.11.001

Kowarik I (1995a) Time lags in biological invasions with regard to the success and failure of alien species. In: Pyšek P, Prach K, Rejmánek M, Wade M (eds) Plant Invasions - General Aspects and Special Problems. SPB Academic Publishing, Amsterdam, pp. 15-38 
Kowarik I (1995b) On the role of alien species in urban flora and vegetation. In: Pyšek P, Prach K, Rejmánek M, Wade M (eds) Plant Invasions - General Aspects and Special Problems. SPB Academic Publishing, Amsterdam, pp. 85-103

Kowarik I, von der Lippe M, Cierjacks A (2013) Prevalence of alien versus native species of woody plants in Berlin differs between habitats and at different scales. Preslia 85:113-132

Krawiecowa A (1951) Analiza geograficzna flory synantropijnej miasta Poznania. Poznańskie Towarzystwo Przyjaciół Nauk, Poznań

Křivánek M, Pyšek P, Jarošík V (2006) Planting History and Propagule Pressure as Predictors of Invasion by Woody Species in a Temperate Region. Conserv Biol 20:1487-1498. doi:10.1111/j.1523-1739.2006.00477.x

Lambdon PW, Pyšek P, Basnou C, Hejda M, Arianoutsou M, Essl F, Jarošík V, Pergl J, Winter M, Anastasiu P, Andriopoulos P, Bazos I, Brundu G, Celesti-Grapow L, Chassot P, Delipetrou P, Josefsson M, Kark S, Klotz S, Kokkoris Y, Kühn I, Marchante H, Perglová I, Pino J, Vilá M, Zikos A, Hulme PE (2008) Alien flora of Europe: species diversity, temporal trends, geographical patterns and research needs. Preslia 80:101-149

Lockwood JL, Cassey P, Blackburn T (2005) The role of propagule pressure in explaining species invasions. Trends Ecol Evol 20:223-228. doi:10.1016/j.tree.2005.02.004

Lonsdale WM (1999) Global patterns of plant invasions and the concept of invasibility. Ecology 80:1522-1536. doi:10.1890/0012-9658(1999)080[1522:GPOPIA]2.0.CO;2

Mandák B, Pyšek P, Bímová K (2004) History of the invasion and distribution of Reynoutria taxa in the Czech Republic: a hybrid spreading faster than its parents. Preslia 76:15-64

McKinney ML (2006) Urbanization as a major cause of biotic homogenization. Biol Conserv 127:247-260. doi: 10.1016/j.biocon.2005.09.005

Pauchard A, Shea K (2006) Integrating the Study of Non-native Plant Invasions across Spatial Scales. Biol Invasions 8:399-413. doi:10.1007/s10530-005-6419-8

Pyšek P (1998) Alien and native species in Central European urban floras: a quantitative comparison. J Biogeogr 25:155-163. doi:10.1046/j.1365-2699.1998.251177.x

Pyšek P, Prach K (1993) Plant Invasions and the Role of Riparian Habitats: A Comparison of Four Species Alien to Central Europe. J Biogeogr 20:413-420. doi:10.2307/2845589

Pyšek P, Křivánek M, Jarošík V (2009) Planting intensity, residence time, and species traits determine invasion success of alien woody species. Ecology 90:2734-2744. doi:10.1890/08-0857.1

Ratyńska H (2001) Roślinność Poznańskiego Przełomu Warty i jej antropogeniczne przemiany. Wydawnictwo Akademii Bydgoskiej, Bydgoszcz, Poland

Richardson DM, Holmes PM, Esler KJ, Galatowitsch SM, Stromberg JC, Kirkman SP, Pyšek P, Hobbs RJ (2007) Riparian vegetation: degradation, alien plant invasions, and restoration prospects. Divers Distrib 13:126139. doi:10.1111/j.1366-9516.2006.00314.x

Rutkowski L (2011) Klucz do oznaczania roślin naczyniowych Polski niżowej. Wydawnictwo Naukowe PWN, Warszawa

Sîrbu C, Oprea A (2008) Two alien species in the spreading process in Romania: Reynoutria x bohemica Chrtek \& Chrtková and Grindelia squarrosa (Pursh) Dunal. Cercetări Agronomice Moldova 41:41-50

Speak AF, Mizgajski A, Borysiak J (2015) Allotment gardens and parks: Provision of ecosystem services with an emphasis on biodiversity. Urban For Urban Green 14:772-781. doi:10.1016/j.ufug.2015.07.007

Statistical Yearbook of Poznań City (2013) Statistical Office in Poznań, Poznań

Sukkop H, Wurzel A (2003) The Effects of Climate Change on the Vegetation of Central Europaean Cities. Urban Habitats 1:66-86

Szymura M, Szymura TH (2013) Soil preferences and morphological diversity of goldenrods (Solidago L.) from south-western Poland. Acta Soc Bot Pol 82:107-115. doi:10.5586/asbp.2013.005

Tabacchi E, Planty-Tabacchi A-M (2003) Recent changes in riparian vegetation: possible consequences on dead wood processing along rivers. River Res Appl 19:251-263. doi:10.1002/rra.755

Tokarska-Guzik B (2005) The Establishment and Spread of Alien Plant Species (Kenophytes) in the Flora of Poland. Wydawnictwo Uniwersytetu Śląskiego, Katowice

Tokarska-Guzik B, Dajdok Z, Zając M, Zając A, Urbisz A, Danielewicz W, Hołdyński Cz (2012) Rośliny obcego pochodzenia w Polsce ze szczególnym uwzględnieniem gatunków inwazyjnych. Generalna Dyrekcja Ochrony Środowiska, Warszawa

Tutin TG, Heywood VH, Burges NA, Valentine DH, Walters SM, Webb DA (1964-1993) Flora Europaea. Cambridge University Press, Cambridge

Urbisz A, Urbisz A, Błażyca B, Tokarska-Guzik B (2009) Uczep amerykański Bidens frondosa. In: Dajdok Z, Pawlaczyk P (eds) Inwazyjne gatunki roślin ekosystemów mokradłowych Polski. Wydawnictwo Klubu Przyrodników, Świebodzin, pp 52-53

Wiens JA (1989) Spatial scaling in ecology. Funct Ecol 3:385-397. doi:10.2307/2389612

Williams NSG, Hahs AK, Vesk PA (2015) Urbanisation, plant traits and the composition of urban floras. Perspect Plant Ecol 17:78-86. doi:10.1016/j.ppees.2014.10.002 
Wojterski T, Wojterska H, Wojterska M (1982) Mapa potencjalnej roślinności naturalnej środkowej Wielkopolski. Bad Fizjogr Pol Zach B 32:7-35

Zając A, Zając M (2001) Atlas rozmieszczenia roślin naczyniowych w Polsce. Pracownia Chorologii Komputerowej Instytutu Botaniki Uniwersytetu Jagiellońskiego i Fundacji dla Uniwersytetu Jagiellońskiego, Kraków

Zając A, Tokarska-Guzik B, Zając M (2011) The role of rivers and streams in the migration of alien plants into the Polish Carpathians. Biodiv Res Conserv 23:43-56

Zerbe S, Wirth P (2006) Non-indigenous plant species and their ecological range in Central European pine (Pinus sylvestris L.) forests. Ann For Sci 63:189-203. doi:10.1051/forest:2005111

Żołnierz L, Klocek I, Pruchniewicz D (2011) Rozwój skupień inwazyjnego słonecznika bulwiastego (Helianthus tuberosus sensu lato) i ich wpływ na roślinność siedlisk antropogenicznych. Acta Bot Sil 6:213-227 